\title{
REFUGIADOS AMBIENTAIS: uma análise da vulnerabilidade da pessoa humana em face da degradação do meio ambiente em virtude do desenvolvimento econômico não ordenado. \\ ENVIRONMENTAL REFUGEES: an analysis of the vulnerability of the human person in the face of the degradation of the environment by virtue of the unordered economic development.
}

\author{
Caroline Vargas Barbosa ${ }^{1 *}$ \\ Carolina Soares Hissa*
}

RESUMO: O trabalho tem por objetivo versar sobre a questão dos refugiados ambientais em virtude do desenvolvimento e crescimento econômico. Aborda legislações ambientais internacionais e nacionais, bem como a questão sobre vulnerabilidade humana e ambiental em virtude da exploração econômica em dissonância com as perspectivas de sustentabilidade. Ao fim traduz esses impactos e os consubstanciam nos movimentos migratórios caracterizados pela concepção de refugiados ambientais. A metodologia foi dedutiva de natureza básica, qualitativa com recursos bibliográficos e documentais. Busca-se a compreensão de um ordenamento ecojurídico que receba o indivíduo em sua completude para além da exploração e desenvolvimento econômico, garantindo a vida.

PALAVRAS- CHAVES: Meio Ambiente. Vulnerabilidade. Desenvolvimento econômico. Refugiados ambientais. Direitos Humanos.

ABSTRACT: The aim of this paper is to address the issue of environmental refugees as a result of economic growth and development. It addresses international and national environmental legislations as well as the issue of human and environmental vulnerability due to economic exploitation in disarray with the prospects of sustainability. Then, these impacts are reflected in the migratory movements characterized by the concept of environmental refugees. The methodology was deductive of a basic, qualitative nature with bibliographic and documentary resources. It seeks to understand an eco-legal order that receives the individual in its completeness beyond exploration and economic development, ensuring life.

KEYWORDS: Environment. Vulnerability. Economic development. Environmental refugees. Human rights.

\section{INTRODUÇÃO}

O trabalho justifica-se na necessidade de análise dos movimentos de deslocados ambientais por necessidade adversa de grandes ações naturais, mas da própria atuação humana nas relações econômicas que impactam gravemente o ambiente em que se vive a ponto da saída forçada de grupos de pessoas em busca de nova condição de existência digna.

O objetivo do artigo é demonstrar como as ações que visam o desenvolvimento e crescimento econômico se não observarem os preceitos de sustentabilidade e humanidade

\footnotetext{
* Mestra em Direito Agrário pela UFG. Especialista em Processo Civil pela UFSC. Advogada e docente em graduação e pós graduação com enfoque em Direito Civil e Direitos Humanos. Contato: profcarol.vargas@gmail.com

* Mestra em Direito Constitucional pela UNIFOR. MBA em Direito Público e Administração Pública pela UCB. Advogada e docente em graduação e pós graduação.na áerea de Constitucional, Internacional e Direitos Humanos. Contato: carolshissa@gmail.com
} 
levarão à existência de grupos de indivíduos que terão direitos humanos mitigados e possibilitarão que se inicie um fluxo migratório em virtude de causas ambientais que são os denominados refugiados ambientais.

A metodologia utilizada foi dedutiva haja vista que parte do conhecimento geral para o específico por meio de cadeia de raciocínio decrescente. A natureza da pesquisa é básica, pois envolve verdades universais e se propõe a gerar novos conhecimentos sem uma aplicabilidade prática imediata. O objetivo do estudo tem viés explicativo por preocupar-se em identificar fatores que ocasionam os movimento dos refugiados ambientais, a abordagem se dá de forma qualitativa, já que o meio natural é fonte de pesquisa, interpretação de fenômenos e atribuição de resultados. No que tange ao procedimento técnico, este de seu por meio de pesquisa bibliográfica e documental.

Assim, em um primeiro momento levanta-se as noções acerca do meio ambiente, fazendo-se um levantamento de tal direito por meio da legislação internacional e, posteriormente, o modo com o Estado brasileiro incorpora em seu ordenamento tal direito fundamental.

Em seguida aborda-se a vulneralibilidade do homem e do ambiente frente ao desenvolvimento econômico que, por muitas vezes, não aplica as diretrizes normativas de preservação ambiental e, consequentemente, ferindo normas de direitos fundamentais, comprometendo tanto a atual geração como as gerações futuras, na medida em que não obedecem a um desenvolvimento sustentável.

Em sua última parte o trabalho desenvolve a relação desse crescimento econômico desordenado que impacta diretamente o meio ambiente e acaba por gerar um movimento migratório com animus de refúgio. Ou seja, a situação ambiental se torna tão crítica que a população se vê obrigada a largar sua própria história, seus próprios direitos humanos em busca de uma nova região onde possa readquirir a essência da dignidade humana.

Demonstra-se, assim, a necessidade de ordenamentos internos compatíveis com a proteção ambiental, com o crescimento econômico sustentável e com esses indivíduos migrantes em razão de impactos ambientais gravosos que comprometem a permanência dos mesmos na área, bem como os das gerações futuras, sendo notável a violação de direitos humanos e mitigação do princípio da dignidade humana. 


\section{O MEIO AMBIENTE NA PERSPECTIVA NACIONAL E INTERNACIONAL}

Os diálogos acerca do meio ambiente comportam um profundo estudo inter e transdisciplinar em um esforço para além da academia estritamente jurídica com o intuito coletivo para proteger o meio ambiente de degradações e desiquilíbrios que podem ocorrer do mau uso consciente do ser humano alicerçado pela omissão ou confronto com a legislação e princípios gerais do Direito.

Em âmbito internacional a proteção com as questões ambientais surgem com mais enfoque nos ano 60 e 70 - do século XX- com a preocupação dos problemas eminentes às questões dos ecossistemas. O que não descaracteriza, nem retira importância dos primeiros tratados sobre a matéria, tais como a Convenção entre França e Grã-Bretanha (1867) que tinha por objeto a proibição da pesca de ostras em determinados períodos; ou a Convenção de Londres de 1900, que apesar de nunca ter entrado em vigor é reconhecido como um marco nas discussões ambiental, que visava a conservação das espécies de animais na África que são úteis ao homem ou inofensivo; a Convenção concernente a exploração e conservação de pescados na fronteira do Rio Danúbio (1902) e a própria Carta da ONU de 1945 exerceu papel importante ao incentivar a adoção de medidas de proteção ambiental na medida em que o propósito da organização é a preocupação com as gerações vindouras e criação de mecanismos que geram melhor condição de vida.

Assim, o leque de ações coordenadas sobre preservação e proteção do ambiente ganha força com a Convenção de Estocolmo (1972), que trata do meio ambiente humano seguida da Conferência das Nações Unidas para o Meio Ambiente e Desenvolvimento, no Rio de Janeiro (1992), conhecida como ECO-92.

A convenção de 1972, também conhecida como Primeira Conferência das Nações Unidas sobre o Meio Ambiente Humano, contou com 113 países, 250 ONGs e vários organismos da ONU. Ocorreu em virtude da constatação mundial dos efeitos que existiam em virtude das mudanças climáticas, do secamento dos rios e da crescente poluição. Este evento trouxe à sociedade mundial a quebra do paradigma de que o meio ambiente seria uma fonte inesgotável de vida e que o maior culpado por toda essa alteração seria o Homem. Desta forma cabia ao Homem criar os mecanismos necessários para a retomada do bem-estar ambiental como condição para a própria existência.

A ECO-92 contou com maior participação passando a contar com 172 países e em torno de 1.400 ONGs, ressalte-se que as Organizações não governamentais realizaram 
acordos em paralelo ao dos Estados. Para este momento a discussão concentrou esforços na tomada de medidas para diminuição da degradação ambiental e a preocupação com as gerações futuras, ou seja, com o direito fundamental de terceira geração de um meio ambiente saudável e sustentável. Aliás, é nesse momento que se propõe um modelo de equilíbrio ecológico aliado às formas de crescimento econômico; um desenvolvimento econômico ${ }^{2}$ pautado em regras de proteção ambiental especialmente no que versa sobre a questão da poluição e implementação de tecnologias não poluentes aos meios de produção.

Do evento foram resultados seis documentos que abordam a matéria de forma mais específica: a Declaração do Rio sobre Meio Ambiente e Desenvolvimento; a Agenda 21; Princípios para a Administração Sustentável das Florestas; a Convenção da Biodiversidade; a Convenção sobre Mudança do Clima e, por fim, a Convenção da Desertificação.

Outro momento de grande relevância para a discussão de mecanismos de proteção ambiental foi o que ocorreu em 1997 na cidade de Quioto no Japão. Na oportunidade foi celebrado um protocolo de intenções pelo qual os países-membros se comprometeriam a reduzir, com metas específicas para cada Estado, a emissão de gases que contribuíam para o chamado efeito estufa entre os anos de 2008 e 2012. A reunião tinha por objetivo maior conscientizar a comunidade internacional que era hora de tomada de medidas drásticas para a redução da poluição ao meio ambiente. Infelizmente os Estados Unidos da América se recusou a assinar o documento sob o argumento que tal ação impactaria diretamente o crescimento econômico de seu país.

Em 2012, prazo dado pelo Protocolo de Quioto para aplicação e coleta de dados das metas estipuladas ocorreu novo encontro, mais uma vez no Rio de Janeiro. A Conferência das Nações Unidas sobre Desenvolvimento Sustentável (CNUDS), conhecida também como

\footnotetext{
$2 \mathrm{O}$ desenvolvimento econômico pode ser conceituado de forma genérica e bem didática como sendo o crescimento econômico acompanhado de forma bem próxima pela melhoria de qualidade de vida da população, assim como, por alterações muito profundas na estrutura econômica de um país, gerando números de análise social substancialmente positivos. Por esta razão pode-se afirmar que o desenvolvimento requer crescimento econômico, contudo não se confunde com ele de qualquer forma. Trata-se de uma análise mais aprofundada em critérios sociais e econômicos. Em razão disto, o desenvolvimento econômico de um país pauta-se em caráter mais qualitativo, visando por fim melhorar os indicadores de bem-estar social e econômico. Índices positivos buscam galgar cada vez maior crescimento, como, por exemplo, saúde, alimentação, transporte, educação, higiene e moradia. Em contrapartida, índices em relação a conceitos negativos devem ser rechaçados e cada vez mais combatidos como a pobreza, o desemprego e violência, dentre outros. (ALMEIDA; HISSA, 2011)
} 
REFUGIADOS AMBIENTAIS: uma análise da vulnerabilidade da pessoa humana em face da degradação do meio ambiente em virtude do desenvolvimento econômico não ordenado.

Rio $+20^{3}$, tinha por objetivo renovar o compromisso de sustentabilidade ambiental de 1997 .

Esta contou com duas temáticas principais: a economia verde no contexto do

desenvolvimento sustentável e da erradicação da pobreza; e a estrutura institucional para o desenvolvimento sustentável. (BRASIL, 2019).

Realizada em 2012, a Conferência das Nações Unidas sobre Desenvolvimento Sustentável (Rio+20) constituiu um dos maiores eventos da história da ONU, contando com a participação de 193 delegações, além de representantes da sociedade civil. O amplo diálogo com a sociedade brasileira fez-se presente desde a preparação do evento, por meio da Comissão Nacional para a Rio+20, que empreendeu consultas com os diversos atores internos para que se chegasse a uma posição brasileira coesa na conferência.

A atuação do Brasil como presidente do evento contribuiu para que o documento final "O Futuro que Queremos" alcançasse resultado equilibrado, atendendo às aspirações de países desenvolvidos e em desenvolvimento. Dentre os principais resultados da Conferência, destaque-se o compromisso assumido pelos Estados com a erradicação da pobreza extrema. Merecem igual atenção o lançamento de processo intergovernamental para a criação dos Objetivos de Desenvolvimento Sustentável (ODS), a criação do Foro Político de Alto Nível sobre Desenvolvimento Sustentável e o incentivo ao fortalecimento do Programa das Nações Unidas para o Meio Ambiente $^{4}$ (PNUMA). (BRASIL - MRE, 2019).

O direito brasileiro especificamente tem elaborado uma legislação ambiental a par dos princípios adotados na Constituição Federal de 1988 e dos direitos fundamentais. Os direitos fundamentais são os constitucionalizados como tanto, depois da necessidade de

\footnotetext{
${ }^{3}$ A Rio+20 foi assim conhecida porque marcou os vinte anos de realização da Conferência das Nações Unidas sobre Meio Ambiente e Desenvolvimento (Rio-92) e contribuiu para definir a agenda do desenvolvimento sustentável para as próximas décadas. A proposta brasileira de sediar a Rio+20 foi aprovada pela AssembleiaGeral das Nações Unidas, em sua $64^{a}$ Sessão, em 2009. (BRASIL, 2019, online).

${ }^{4}$ Paulo Artaxo, membro da coordenação do PFPMCG, destacou que as menções à questão das mudanças climáticas também foram quase nulas. "O texto final da RIO+20 tem 53 páginas, divididas em 283 tópicos. Desse total, apenas três tópicos mencionam a questão do clima. Para se ter uma ideia, há seis tópicos sobre igualdade de gênero e dez sobre lixo químico - que são temas importantes, mas não envolvem a mesma escala e urgência do problema do clima", disse. Além da escassez, o conteúdo das menções à questão do clima é muito vago, segundo Artaxo. "O texto se limita a afirmar que as mudanças climáticas estão entre os maiores desafios do nosso tempo e que o tema gera preocupação, por exemplo", disse. Para o pesquisador, no entanto, seria ingenuidade acreditar que a conferência poderia trazer soluções imediatas para a questão da sustentabilidade global. A oportunidade perdida na conferência foi a de contribuir para acelerar as decisões necessárias. "O problema é enorme e envolve todo o sistema de produção que roda a economia e a política de todo o nosso planeta. Uma questão desse porte não pode ser resolvida em uma única reunião, ou mesmo em uma década. $\mathrm{O}$ equacionamento vai demorar pelo menos mais 10 anos - o nosso problema é que não temos todo esse tempo", disse. Para Artaxo, a RIO+20 evidenciou que o mundo se ressente da falta de governança para lidar com a questão do clima global. "Não temos entidades que possam implementar políticas globais com impacto importante na economia do planeta para enfrentar os desafios do clima. Se é difícil reduzir emissões de $\mathrm{CO}^{2}$, poderíamos tentar reduzir as emissões de metano e ozônio, por exemplo. Mas isso exige um sistema de governança que a RIO+20 mostrou claramente não existir", afirmou. Fábio Feldman, do Fórum Paulista de Mudanças Climáticas, apontou que a falta de liderança pode ter comprometido os resultados da RIO+20. Segundo ele, a RIO92 (ou ECO-92), por exemplo, obteve mais sucesso porque na época o interlocutor brasileiro com os chefes de estado foi o físico José Goldemberg. (FAPESP, 2019, online).
} 
intervenção estatal no bem estar social, como normas programáticas e de eficácia plena. Querse dizer, são garantias-compromissos do Estado com os indivíduos, são necessárias então ações do Estado para a garantia deles. Surgem as políticas públicas e estatais, além das normas infraconstitucionais visando o maior alcance para garantia e eficácia. Os direitos fundamentais uma vez constitucionalizados, somente por meio da Constituição deixam de ser fundamentais.

No nosso ordenamento jurídico são elencados por gerações. Os direitos de solidariedade e fraternidade são considerados fundamentais de terceira geração. Comportam os direitos de titularidade coletiva e difusa, na figura do homem-indivíduo da sociedade singular. O direito ao meio ambiente, qualidade de vida, paz, e vinculação do qual tratamos neste trabalho de relação do homem com o meio ambiente como elemento vital, insere-se neste aspecto (SARLET, 2018).

A transgressão de normas e princípios constitucionais invade uma seara muito mais complexa, eis que compromete todo o texto constitucional ao mesmo passo que entra em ruína todo o sistema sociopolítico além do jurídico, corroendo princípios morais e éticos que foram institucionalizados como berço democrático pressupondo uma mudança social de garantia estatal de direitos mínimos e de novas e iguais oportunidades (MELLO, 1992).

\section{VULNERABILIDADE AMBIENTAL E HUMANA: UMA AMEAÇA À PAZ E À SEGURANÇA INTERNACIONAL}

O capitalismo transforma o meio ambiente em mercadoria fictícia e impõe um sistema de mercado baseado no trabalhador assalariado. $\mathrm{O}$ meio ambiente como um direito difuso e coletivo sofre restrições intervencionista por meio do Estado, para que regule seu mercado e condicione os indivíduos, proprietários ou não, a um mesmo fim: o da geração de renda (lucro) e a garantia de acesso indiscriminado ao meio ambiente de qualidade para estas e futuras gerações. No entanto, o meio ambiente comporta características singulares de geração de renda: pela produção, como reserva de mercado, pela manutenção, pela extração ou venda. Em razão destas singularidades, combinado, com uma contenção social, o Direito supre a regularização de mercado por meio de leis e politicas públicas ou estatais de incentivo econômico e proteção social. 
O homem nesse aspecto tem a relação com o meio ambiente de duas formas. A primeira coerente com o desenvolvimento capitalista, de onde retira da terra sua fonte de lucro. A segunda como uma relação vital de manutenção da vida. O vínculo primitivo do homem com a natureza, e do emprego do trabalho como meio de subsistência, respeitando a terra e usando-a de acordo com o ciclo vital, emanando pelas ordens ambientais.

Mas em que momento, homem, capitalismo e meio ambiente conseguem encontrar a congruência? As antagônicas prospecções do uso e utilidade do meio ambiente, resultam em um processo de exclusão e negligência de direitos. Enquanto assevera-se a proteção a propriedade privada, excluem-se os que não a tem. O poder aquisitivo e a extração de riquezas ambientes cerceia o uso da qualidade do meio ambiente dos demais. Da mesma forma, a proteção socioambiental do meio ambiente, é considerada insuficiente para o capitalismo e o Estado, que não enxerga a policultura rentável ao desenvolvimento econômico, embora entenda-se primordial ao reconhecimento de direitos sociais e fundamentais. O confronto de ideais, supera as normativas jurídicas ou decisões estatais, e encontra valores éticos, sociais, históricos e ideológicos. No entanto, o capital tudo quantifica e só reconhece o cálculo das cifras de produção. Por isso, há submissão da sociedade perante a economia. Ou seja, existe de fato uma dominação do valor de troca da mercadoria em troca da destruição de quaisquer valores éticos (LÖWY, 2005).

A ausência de moral e o máximo valor de troca é fundamento para o capitalismo. Justifica-se a ausência de moral nas contradições que o próprio capitalismo gera pela individualidade de interesses. O capitalismo se apropria das demandas dito ecológicas para transformá-las em demandas ecocapitalistas ainda pautada na exploração e geração de lucros, mas com uma roupagem de sustentabilidade e zelo ambiental. E o descompromisso de solução destas contradições, pois é justamente neste aspecto, que se fortalece o capitalismo: na contradição e exclusão. A acumulação material fica dissociada de valores morais e das necessidades humanas condicionais ao indivíduo, como por exemplo o bem estar social, e transmuta qualidades em produtos no mercado de trabalho (GIDDENS, 2005).

Além de que, pela afirmação do Estado e da ordem jurídica há a proteção necessária para o fortalecimento do capitalismo. Isso porque, a regulação pela via normativajurídica, confere o espaço para o crescimento econômico de maneira legítima. E quando a intervenção estatal gera um conflito de interesses o capital se reestrutura para que mantenha seu domínio. Portanto, o interesse estatal, não é a reestruturação social, defasada pela 
Revolução Industrial e pelo incremento do capitalismo. É sim, uma medida protecionista econômica, que não desmantele a sociedade, para que ainda haja força de trabalho, agindo na contenção das disparidades sociais.

O meio ambiente é um elemento holístico e fundamental, portanto, à vida humana. Aborda então interesse econômico, político e social. Social na medida que intrínseco ao homem, econômico pois como mercadoria para o capitalismo vincula a geração de renda e pelo Estado na regulação do mercado, manutenção do equilíbrio social e proteção de divisas, portanto, evidenciada a vertente política.

Temos uma dissociação do homem com a natureza, motivado pelo capitalismo. O fenômeno da quantificação do meio ambiente, dá ensejo às primitivas e insustentáveis formas de produção humana, nas quais interesses econômicos, políticos e empresariais se sobrepõem à questão do vínculo com a terra de maneira vital, como se o meio ambiente pudesse ser utilizado como fonte inesgotável para a acumulação de capital. Nessa perspectiva de dissociação, há necessidade do homem se perceber como parte integrante do meio ambiente e não vê-lo como meio de obtenção do que deseja, sem pensar nas consequências que a sua utilização pode acarretar. Precisa se conscientizar que as ações econômicas devem respeitar o meio ambiente e os direitos das coletividades, o que o capital, por si, é incapaz de fazer. A tomada de consciência de que a degradação da terra pode atingir os direitos dos seres humanos à uma vida digna e saudável, tira a concepção da propriedade da terra e seu uso de uma pauta secundária, tornando-a eminentemente primordial (BALIM, 2012).

A dissociação do homem com o meio ambiente e a exploração insustentável do meio ambiente acaba tornando insuportável e intolerável a manutenção da vida humana (quando não, a não humana também) e faz com que o homem retome os princípios nômades deixando sua pátria em busca da possibilidade de viver. Temos a vulnerabilidade humana diante da dissociação do homem com o meio ambiente fortalecida pelas praticas exploratórias e de acumulação do capital que vê-se cerceado de direitos fundamentais como o acesso ao meio ambiente e vê-se impelido a buscar novos lugares para estabelecer moradia ante a devastação aflitiva de seu local de origem.

Com a criação da Organização das Nações Unidas, inaugurou-se na perspectiva internacional baseada em um ideal kantiano a ideia e conceito de paz, visando não apenas uma necessidade de organização dos Estados a fim de garantir uma paz mas que esta fosse 
REFUGIADOS AMBIENTAIS: uma análise da vulnerabilidade da pessoa humana em face da degradação do meio ambiente em virtude do desenvolvimento econômico não ordenado.

perpetua erradicando a violência dos conflitos e suas consequências e investigando suas causas (OLIVEIRA, 2017). Nesse sentido:

\begin{abstract}
Os estudos de paz, nessa fase, abrangiam as questões humanitárias, em virtude do contexto histórico da época (guerras mundiais) e das décadas seguintes, também permeadas por inúmeros conflitos (implosão de Estados violentos, guerras civis, catástrofes humanitárias com práticas de genocídio e limpeza étnica) a clamarem pela solidariedade e cooperação internacional, especialmente no que pertine à assistência às vítimas, submetidas a violações sistemáticas dos seus direitos humanos.
\end{abstract}

Percebemos então que a paz não se restringe a preocupação das questões de violência entre os povos, genocídios ou restrição de direitos civis e políticos, mas também evitar a promoção de conflitos inclusive de questões ambientais provocadas pelo homem e pela ausência de zelo ambiental, fazendo com que os indivíduos busquem o meio ambiente de qualidade ou para sobreviver ou ampliando o espectro de exploração (AMARAL, 2003).

Ainda, podemos perceber que as questões ambientais alicerçadas no conceito de paz da ONU são contempladas pela Resolução 43/131 que prevê a assistência humanitária às vitimas de catástrofes naturais (ONU, 1988). Em 1999, a continuidade desse pensamento foi criado por meio da Declaração e Programa de Ação sobre Cultura e Paz:

Artigo 1. Uma Cultura de Paz é um conjunto de valores, atitudes, tradições, comportamentos e estilos de vida baseados:

a) No respeito à vida, no fim da violência e na promoção e prática da não-violência por meio da educação, do diálogo e da cooperação;

b) No pleno respeito aos princípios de soberania, integridade territorial e independência política dos Estados e de não ingerência nos assuntos que são, essencialmente, de jurisdição interna dos Estados, em conformidade com a Carta das Nações Unidas e o direito internacional;

c) No pleno respeito e na promoção de todos os direitos humanoseliberdades fundamentais;

d) No compromisso com a solução pacífica dos conflitos;

e) Nos esforços para satisfazer as necessidades de desenvolvimento e proteção do meio-ambiente para as gerações presente e futuras;

f) No respeito e promoção do direito ao desenvolvimento;

g) No respeito e fomento à igualdade de direitos e oportunidades de mulheres e homens;

h) No respeito e fomento ao direito de todas as pessoas à liberdade de expressão, opinião e informação;

i) Na adesão aos princípios de liberdade, justiça, democracia, tolerância, solidariedade, cooperação, pluralismo, diversidade cultural, diálogo e entendimento em todos os níveis da sociedade e entre as nações;

e animados por uma atmosfera nacional e internacional que favoreça a paz.

Portanto, a visão de paz abarca a concepção de dois momentos: o primeiro evitar conflitos (armados ou não) que coloquem em xeque a construção da solidariedade entre os 
Estados e a manutenção de uma preservação ambiental por meio do desenvolvimento sustentável que garanta uma vida digna e padrões de qualidades ambientais a fim de corroborar para a estabilidade dos povos. A manutenção então desses padrões, se dividem em uma tríade: evitar o desenvolvimento antagônico a preservação sustentável do meio ambiente; inibir conflitos entre Estados inclusive com o uso de degradação ambiental como tática de guerra; e, as catástrofes ambientais ditas naturais.

Outro aspecto a ser pautado é a questão da segurança em linhas internacionais. Temos uma perspectiva multidimensional de segurança que, para além do significado tradicional, deve incorporar a pós-modernidade e as questões ambientais, uma preocupação não de hoje:

Cada vez mais, os países estão encontrando sua segurança prejudicada por ameaças
ambientais emanadas de outras nações, como poluentes que atravessam suas
fronteiras através do ar ou da água, ou inundações cataclísmicas desencadeadas por
bacias hidrográficas desnudadas, longe de suas fronteiras. Em escala global, as
mudanças climáticas, o esgotamento do ozônio, a deterioração da base agrícola e o
desmatamento são desafios formidáveis para a segurança o bem-estar de toda a
raça. Ameaças ambientais com o potencial de corroer a habitabilidade do planeta
debaixo de nós estão forçando a humanidade a considerar a segurança nacional em
termos muito mais amplos do que aqueles garantidos unicamente pela força das
armas (RENNER, 1989).

De modo que, a demanda da atualização do termo segurança a par das degradações ambientais é também uma convergência de políticas de segurança internacionais aliadas a questões de interesses econômicos, políticos, sociais fixando compromissos para a manutenção da segurança. As mudanças climáticas, as formas de apropriação do meio ambiente como mercadoria, as explorações capitalistas, as práticas políticas sem compromisso com os indivíduos, os direitos fundamentais e humanos entre outras ações e omissões são fontes diretas de causas que prejudicam a estabilidade da segurança internacional, com o rompimento de pactos e solidariedade internacional corroborando para que indivíduos se vejam cerceados de seus locais de origem e premidos de necessidade de buscar novos espaços para viver. Chegamos quase ao ponto de uma nova globalização, agora de emergência ambiental (NASCIMENTO, 2010).

Nesse momento, temos a visão não-cartesiana do meio ambiente. O meio ambiente não tem fronteiras como os Estados. Ela não tem limitações territoriais. Seus 
REFUGIADOS AMBIENTAIS: uma análise da vulnerabilidade da pessoa humana em face da degradação do meio ambiente em virtude do desenvolvimento econômico não ordenado.

sujeitos são difusos e coletivos. A prática de preservação e zelo ambiental deve ser incorporada por todos os Estados, indistintamente, para garantir a promoção destes direitos. Por, repensar as formas econômicas de exploração e da ideia de ecocapitalismo refere-se a tratar as injustiças sociais para que não gere injustiça das relações com a natureza, proporcionando a todos, o acesso aos direitos ambientais de forma indiscriminada. Trata-se de uma concepção ética de responsabilidade compartilhada entre os Estados e povos (OST, 1997). Essa concepção ética, pode interferir em uma revolução ecojurídica numa perspectiva de um ordenamento jurídico utilizado por cidadãos ecoalfabetizados e engajados com reconhecimento de cidadania pela democracia e atividades comissivas dos Estados por meio de políticas de Estado e públicas para a promoção e segurança desses direitos. Retomamos a ideia de direito natural ao meio ambiente a ser reconhecido, promovido e garantido pelos Estados (CAPRA; MATTEI 2018).

É assim evidente que os eventos ambientais extremos têm causas e/ou efeitos em níveis mundiais causando a preocupação e a tomada de responsabilidade para além das fronteiras em um esforço internacional para inclusive abarcar a noção de paz e segurança evitando crises humanitárias e projeções para uma sociedade. A preocupação ambiental e a escassez de recurso faz com que houvesse uma retomada da ideia de procurar novas divisas em busca do meio ambiente adequado (como antigamente fora feito com a produção de mercadorias) sendo inclusive motivo de conflitos internacionais:

Muitos analistas têm argumentado ultimamente que a maior parte dos conflitos armados no futuro próximo estará relacionada a problemas ambientais, como mudanças climáticas, o aumento do nível dos mares, e a escassez de água potável, gerando uma acirrada disputa por recursos e territórios mais seguros. Assim, os países passariam a desenvolver poderosas armas para defender ou assegurar a posse de alimentos, água e estoques de energia, em que a estabilidade global estaria seriamente ameaçada (FERNANDES, 2006).

Nessa, perspectiva é necessário refletir acerca dos indivíduos e grupos que se movem impelidos pela degradação ambiental para garantir a sobrevivência causando parâmetros necessários para pautar novos caminhos de garantia da segurança e paz internacional. Assim:

(...) a questão dos refugiados ambientais promete estar entre uma das maiores crises da humanidade dos nossos tempos. Até o momento, no entanto, ela tem sido vista como uma preocupação periférica, uma espécie de aberração da ordem normal das coisas - mesmo que seja uma manifestação externa de profunda privação e desespero. Enquanto deriva principalmente de problemas ambientais, gera inúmeros problemas de tipo político, econômico e social. Como tal, ele poderia facilmente se 
tornar uma causa de tumulto e confronto, levando a conflitos e violência (MYERS, 1995).

Visualizamos assim, a tomada de consciência ambiental ante a vulnerabilidade do indivíduo e do meio ambiente em proporções geométricas e intrinsicamente ligadas para uma reflexão e construção de uma normativa ecojurídica em nível internacional como forma de consolidação da questão ambiental e uma dimensão profunda de garantia da paz, segurança e proteção de direitos humanos que deve ser garantida pelos Estados e comunidade internacional a par de uma autoconscientização dos cidadãos na prática diária.

\title{
3. MOVIMENTOS MIGRATÓRIOS E A PERSPECTIVA PRINCIPIOLÓGICA DOS DIREITOS HUMANOS AOS REFUGIADOS AMBIENTAIS
}

Diversos institutos conceituam o movimento migratório sob diversas perspectivas. Traçar um liame pra compreender a similaridade e diferenças com o fito de contribuir para uma acepção, principalmente, hermenêutica do termo refugiados ambientais é de extrema necessidade para um reconhecimento do direito internacional.

O Glossário sobre Migração ${ }^{5}$ (2009) da Organização Internacional de Migração distingue os termos de Migração, Emigração e Imigração. Assim temos que migração referese ao processo de deslocamento de indivíduos estrangeiros por exclusiva escolha para estabelecerem morada que independe da causa e da extensão em busca de melhores prospecções e condições de vida e não por situações de ameaça direta à vida. De outra banda, o termo emigração, é definido como:

\begin{abstract}
Abandono ou saída de um Estado com a finalidade de se instalar noutro. As normas internacionais sobre direitos humanos prevêem que toda a pessoa deve poder abandonar livremente qualquer país, nomeadamente o seu próprio, e que, apenas em circunstâncias muito limitadas, podem os Estados impor restrições ao direito de um indivíduo abandonar o seu território.
\end{abstract}

\footnotetext{
${ }^{5}$ Não se pode esquecer que o ato de migrar é um direito humano formado por um binômio (SQUEFF, 2018, online) "se toda pessoa tem o direito de sair livremente de qualquer país, inclusive do próprio, como prevê o artigo 22(2) da Convenção Americana de Direitos Humanos (OEA, 1969), ela também tem o direito de entrar em outro".
} 
Ao se falar sobre migrações se faz necessário contextualizar que a essência da normatização dos conceitos é proporcionar o exercício de cidadania onde quer que este indivíduo esteja. Nessa perspectiva é preciso sair do conceito comum de cidadania, aquela de âmbito jurídico, que a denomina como a junção do exercício dos direitos civis e doa direitos políticos. Comporta então, para início da abordagem da temática proposta a compreensão do conceito do termo aqui adotado. A concepção aqui escolhida é aquela que divide a cidadania nas projeções de sentido amplo e restrito.

Esta conceituação ampla, na seara dos direitos humanos, foi trabalhada por Marshall (1967) ao relacionar a cidadania a uma espécie de igualdade humana, onde fatores como a desigualdade social e econômica geram atuações determinantes do indivíduo no convívio em sociedade e do usufruto dos direitos e garantias a ele inerentes. Assim, a cidadania abrange os direitos civis, políticos e sociais do ser humano.

Cabe mencionar que por razões específicas - a questão do exercício de direitos de garantias do migrante- se optou pelo sentido mais amplo, que corrobora com ideia de uma sociedade democrática (DEZORDI WERMUTH, online) onde a atuação política estatal deva buscar a redução de qualquer forma de exclusão sempre tendo por base a condição real de uma existência digna.

A OIM compreende ainda a possibilidade da interpretação do termo migrante ambiental para os grupos ou pessoais que devido repentinas alterações ambiental torne insustentável ou extremamente negativa as condições de vida, sendo cerceados a deixar as residências habituais de forma temporária ou permanente dentro do próprio país ou para o estrangeiro. Demonstra-se mais uma vez, a preocupação internacional em permitir o fluxo migratório, de forma regulamentada, sempre que a cidadania em sentido amplo não for respeitada, ou seja, sempre que a vida digna não possa ser exercida.

Outrossim, temos o termo asilo. Tal instituto talvez seja o mais restrito hermeneuticamente de todos os demais, visto que se tem como principal quesito o cunho político visto que propõe-se a proteger o indivíduo da jurisdição do próprio Estado de origem e pauta-se pelo princípio do non-refoulement ${ }^{6}$. No entanto, é possível visualizar na doutrina o termo asilo ambiental, mas ainda de forma discreta (TAMER; POZZETI, 2013).

\footnotetext{
${ }^{6}$ Princípio previsto na Convenção de Genebra Relativa ao Estatuto dos Refugiados, de 1951, de acordo com o qual "Nenhum dos Estados Contratantes expulsará ou repelirá ("refouler") um refugiado, seja de que maneira for, para as fronteiras dos territórios onde a sua vida ou a sua liberdade sejam ameaçadas em virtude da sua raça, religião, nacionalidade, filiação em certo grupo social ou opiniões políticas.” (OIM, 2009)
} 
O termo refugiado passa a ter algumas definições distintas a par do Estatuto dos Refugiados de $1951^{7}$. O instituto refugiado por mandato para aquele indivíduo que merece proteção das Nações Unidas e deve ser facultado pelo Alto Comissariado independente de requisitos ou de não encontrar-se em país que faz parte da Convenção relativa ao Estatuto dos Refugiados. O instituto refugiado de facto refere-se ao indivíduo que não é reconhecido pelo Estatuto e que não pode ou não (por razões reputadas como válidas) quer retornar ao país de nacionalidade ou não possui nacionalidade. Temos ainda o refugiado reconhecido que por receio de ser perseguido em razão de raça, religião, nacionalidade, filiação e por questões políticas pede auxílio e guarida ao país de destino. Refugiado ${ }^{8}$ a posteriori é definido como a pessoa que ao abandonar seu país de origem não o faz como refugiada, no entanto, posteriormente passa a ter fundado receio de perseguição do país de origem. Refugiado em órbita e em trânsito, referem-se respectivamente ao indivíduo que não encontra um país disposto a examinar seu pedido e ao indivíduo que é admitido temporariamente sob condição de ser reinstalado em outro país.

Traçados esses liames iniciais, podemos aprofundar a necessidade de uma interpretação holística visto as necessidades e demandas ambientais para que possamos compreender a hermenêutica do termo refugiado ambiental. Se passarmos a compreender que o indivíduo que é cerceado de manter-se em seu local de origem visto a impossibilidade ambiental de manutenção de vida, pode buscar outros sítios para resgatar e preservar seus direitos humanos internacionais, passamos a compreender a necessidade de conceituar o termo de refugiado ambiental.

Na década de 1970 temos o aparecimento do termo refugiado ambiental por Lester Brown (BLACK, 2001), no entanto, foi com o trabalho de Essam El-Hinnawi

\footnotetext{
${ }^{7}$ A Convenção de 1951 definia a aplicação do instituto para fatos que tivessem ocorrido antes de $1^{\circ}$ de janeiro de 1951. O seu protocolo adicional de 1967 traz uma interpretação extensiva do conceito dado na Convenção- na medida em que retira a aplicação do lapso temporal e das consequências deste marco, faz nova incorporação de texto normativo internacional. Porém, apesar da referência na maioria das obras ser a norma matricial de 1951, é a Declaração de Cartagena, datada de 1984 quem incorpora as três maiores vertentes da proteção ao refugiado: o direito humanitário, os direitos humanos e o direito dos refugiados.

${ }^{8}$ Flávia Piovesan trabalha o encontro entre direitos humanos em 4 momentos fundamentais, pois acredita eu os refugiados devam ter seus direitos fundamentais protegidos antes, durante e depois do processo de solicitação da proteção. O modo como o país acolhe o migrante é o terceiro período de refúgio e o quarto momento é quando se dá uma solução ao problema do solicitante do instituto. (PIOVESAN, 2009). Assim, as preocupações estatais do país acolhedor correspondem a metade do processo, isto posto, são necessárias políticas públicas especificas e efetivas para a demanda migratória.
} 
REFUGIADOS AMBIENTAIS: uma análise da vulnerabilidade da pessoa humana em face da degradação do meio ambiente em virtude do desenvolvimento econômico não ordenado.

(ESMPU, 2006) que o termo ganhou mais notoriedade, identificando os refugiados ambientais como:

[...] forçadas a deixar seu habitat natural, temporária ou permanentemente, por causa de uma marcante perturbação ambiental (natural e/ou desencadeada pela ação humana), que colocou em risco sua existência e/ou seriamente afetou sua qualidade de vida. (EL-HINNAWI, 1985, apud RAIOL, 2010)

Ocorre que algumas dúvidas foram suscitadas quanto a necessidade ou fundada necessidade acerca do deslocamento, a preocupação da extraterritorialidade visto que para o status de refugiado é primordial, não se levando em conta, por exemplo, as questões internas de alterações ambientais que dão ensejo a possíveis casos de migrações ambientais internas. Outro ponto bastante controverso versa acerca do uso de "perturbação ambiental" natural ou por ação humana visto a amplitude conceitual de perturbação ambiental e a falibilidade quanto a ação humano não dispondo também da omissão.

Na década de 80 surge uma segunda onda conceitual trazida por Jodi L. Jacobson:

[...] aquelas pessoas temporariamente deslocadas devido a perturbações ambientais locais, como avalanches ou terremotos; aqueles que migram por causa da degradação ambiental que tem prejudicado a sua subsistência ou apresenta riscos inaceitáveis para a saúde; e aqueles reassentados porque a degradação da terra resultou em desertificação ou por causa de outras mudanças permanentes no habitat. (JACOBSON, 1988, apud RAMOS, 2011)

Posteriormente o Programa das Nações Unidas para o Meio Ambiente (PNUMA) também reflete acerca do termo acrescentando a imposição do deslocamento:

Refugiados ambientais são pessoas que foram obrigadas a abandonar temporária ou definitivamente a zona tradicional onde vivem, devido ao visível declínio do ambiente (por razões naturais ou humanas) perturbando a sua existência e/ou a qualidade da mesma de tal maneira que a subsistência dessas pessoas entra em perigo. Por declínio do ambiente se quer dizer, o surgir de uma transformação, tanto no campo físico, químico e/ou biológico do ecossistema que, por conseguinte, fará com que esse meio ambiente temporário ou permanentemente não possa ser utilizado. (PNUMA, 1985)

Os direitos humanos surgem como um reconhecimento paritário ao direito natural de direitos intrínsecos aos humanos sem distinções de quaisquer naturezas garantindo o mínimo de dignidade, igualdade liberdade dos povos. Trata-se de uma proteção internacional que é alicerçada internamente pelos Estados como um comprometimento ao seu reconhecimento e eficácia. Outrossim, podemos compreender que os princípios do Direito como sua fonte são na verdade os direcionamentos de quaisquer ordenamentos jurídicos, 
fornecendo o amparo para o positivismo e também para as ações de cada Estado em sua promoção.

Considerando que os refugiados ambientais encontram-se em uma situação de extrema vulnerabilidade por ser obrigados a deixar seus locais de origem e buscar meios mínimos de sobrevivência e encontro de direitos ambientais adequados. Considerando, ainda, como trabalhamos nesse texto, que os direitos ambientais são de sujeitos coletivos e difusos temos a necessidade de garantia para além de fronteiras geográficas como meio de manutenção da vida humana e não humana.

Quando ingressam em novos territórios, em situação de refúgio encontram ambientes culturalmente diferentes, de possível rejeição social, racial, religiosa, cultural, ideológica entre outros e de uma difícil adaptação inclusive ambiental visto o comportamento singular em determinadas regiões. Compreende-se assim, a importância do diálogo acerca o tema, para a prática de ações políticas e públicas do Estado para minimizar as dificuldades e oferecer condições mínimas de dignidade ao refugiado ambiental.

Assim em uma sequência de artigos a Declaração Universal de Direitos Humanos deixa clara a intrínseca relação com o tema abordado:

\footnotetext{
(...) Artigo III Todo ser humano tem direito à vida, à liberdade e à segurança pessoal. (...)

Artigo VI Todo ser humano tem o direito de ser, em todos os lugares, reconhecido como pessoa perante a lei. (...)

Artigo VIII Todo ser humano tem direito a receber dos tribunais nacionais competentes remédio efetivo para os atos que violem os direitos fundamentais que lhe sejam reconhecidos pela constituição ou pela lei. (...)

Artigo XXVIII Todo ser humano tem direito a uma ordem social e internacional em que os direitos e liberdades estabelecidos na presente Declaração possam ser plenamente realizados. (DUDH, 1948)
}

Por tal razão, visando honrar os direitos expostos acima, temos que a ACNUR (1967) por meio da Convenção e Protocolo relativos ao Estatuto dos Refugiados, buscaram assegurar tais direitos. Ao determinar a proteção dos direitos individuais e sociais do refugiado na esfera internacional, e, impõe o mesmo aos países signatários a fim de que esses garantam ao refugiado em suas fronteiras o acesso aos direitos fundamentais e humanos, coletivos e difusos, como a proteção em busca de um meio ambiente equilibrado e de qualidade que proporcione o mínimo de dignidade na manutenção da vida. 
A omissão de normatização ou regulamentação específica acerca dos ferimento dos direitos individuais ou sociais do indivíduo, faz com que o organismo internacional e o país receptor do refugiado aplicar os princípios universais dos direitos humanos de forma entrelaçada com os de direito internacional. Percebemos aqui, a necessidade primária de assegurar os direitos individuais necessários a manutenção da vida, como alimentação, local para moradia e repouso, vestuário e acesso a saúde, que inclusive, agrega conceitos de equilíbrio ambiental e sanitário. Em um segundo momento, os direitos que garantem a continuidade da vida e da dignidade da pessoa, como o direito ao trabalho, propriedade, entre outros.

Cabe ao país receptor do refugiado, dentro de sua legislação, possibilidades e ações políticas prestar auxílio, por vezes oneroso, oferecendo assistência ao refugiado ambiental. Dentre as práticas, não somente o recebimento deste indivíduo, mas assistência humanitária mínima de subsistência, perpassando inclusive, possibilidades de adequação cultural e social, projetos de inclusão, fomento de trabalho e inserção político-social do indivíduo garantindo o empoderamento para a (re) construção e manutenção da vida.

\section{CONCLUSÃO}

Se o capitalismo se utiliza da vulnerabilidade do indivíduo em diversos aspectos para além da expropriação da força de trabalho a de se pensar quais são seus limites quando enfrentados o meio ambiente em sua natureza não renovável como meio principal de manutenção da vida. Um ordenamento jurídico pautado em uma normatividade excludente não reflete sobre os indivíduos, e, seus direitos mínimos e humanos passam a ser pautas programáticas de cartas (inter) nacionais.

Compreender o sistema capitalista de forma paritária as necessidades humanas faz-nos refletir acerca de uma norma que seja para os indíviduos, para sujeitos coletivos e difusos e para a natureza que garante a continuidade da vida e não para somente políticoeconômica. Se, por de trás do manto intocável do capitalismo temos o desenvolvimento das nações, este nos são orientados como desenvolvimento econômico para que depois seja possível agregar o social. Em outras construções sociais e em algum momento histórico, talvez seja possível, não mais. O (des) envolvimento do indivíduo parte primeiramente do (re) conhecimento de si e dos seus direitos. Enxergar a sua relação com o meio ambiente e ressignificá-la para além da exploração em cifras em detrimento da ausência de vida. Feito 
isso, uma ordem jurídica que consolide o indíviduos como central em quaisquer debates, e, então a proteção ambiental.

Os direitos humanos então e a proteção ao indivíduo em sua integralidade quaisquer sejam seus territórios, nacionalidades, etnias surgem como forma de se concretizar essa ideia. No entanto, sem a concepção ecocapitalistas, balizada na sustentabilidade da natureza, não conseguimos ter uma compreensão da defesa integral do ser humano. Por isso, um ordenamento jurídico construído na ideia ecojurídica traz a centralidade do debate para o indivíduo e a natureza em respeito aos direitos humanos. Sem uma norma jurídica criada como centralidade um sistema ecojurídico não temos a devida atenção e proteção a direitos humanos básicos de sustentabilidade do meio ambiente e sobrevivência dos indíviduos. Ante a vulnerabilidade do indivíduo em um sistema voltado a exploração capitalista sem que i eixo central seja a hermenêutica de uma sistema aliado aos preceitos de sustentabilidade ambiental, temos cada vez mais, a necessidade de pessoas de buscarem a chance de viver além dos seus territórios ingressando em outros países.

A questão dos refugiados ambientais toma contornos inter(nacionais) de proporções que temos acompanhado que os Estados não estão prontos a suprir as demandas. O Estado passa a ter que garantir o direito ambiental fora dos traços geográficos de suas fronteiras e ainda receber esses indivíduos vulneráveis dispondo de recursos financeiros e políticas de Estado e públicas. Onera-se assim, a máquina pública para suprir os lucros do capitalismo que não foram ofertados a todos. Os lucros desse capitalismo, continuam nas mãos de uma minoria, enquanto a maioria busca sobreviver e ter acesso mínimo a direitos humanos ambientais e sobrevivência. Mais uma vez, o indivíduo vulnerabilizado e o Estado acabam sendo responsáveis pela sistema político-econômico adotado em contracorrente de um ordenamento jurídico que deveria não ser programático ao defender os interesses difusos e coletivos, que deveria garantir o acesso e a eficácia desses direitos indistintamente e por fim deveria pautar o humano em sua integralidade ambiental e holística para sua formação, perpetuação, segurança e vida.

\section{REFERÊNCIAS:}

ALMEIDA, Nathalie Alves de; HISSA, Carolina Soares. Os fluxos migratórios mundiais e a atração populacional em razão do crescimento e desenvolvimento econômico estatal 
brasileiro. In: XVIII Encontro de Iniciação à pesquisa da Universidade de Fortaleza. Disponível em: https://uol.unifor.br/oul/conteudosite/?cdConteudo=3310165 . ISSN 18088449.

AMARAL JÚNIOR, Alberto do. O direito de assistência humanitária. Rio de Janeiro: Renovar, 2003.

BALIM, Ana Paula Cabral. Indivisibilidade socioambiental: Por uma visão integracionista entre os direitos sociais e a proteção ao meio ambiente. REDESG / Revista Direitos Emergentes na Sociedade Global. Disponível em: www.ufsm.br/redesg , v. 1, n. 1, jan.jun/2012.

BLACK, Richard. Environmental Refugees: myth or reality? Working Paper n. 34, Geneva, March, 2001.

BRASIL. MINISTÉRIO DAS RELAÇÕES EXTERIORES. A Rio+20 e seus resultados. Disponível em: http://www.itamaraty.gov.br/pt-BR/politica-externa/desenvolvimentosustentavel-e-meio-ambiente/131-a-rio-20-e-seus-resultados. Acesso em: 15 jan 2019.

RIO+20. Sobre a RIO+20. Disponível em:

http://www.rio20.gov.br/sobre_a_rio_mais_20.html. Acesso em 15 jan 2019.

CAPRA, Frijot; MATTEI, Ugo. A revoluçãoo ecojurídica: o direito sistêmico em sintonia com a natureza e a comunidade. São Paulo: Editora Cultrix, 2018.

DEZORDI WERMUTH, Maiquel Angelo; OXLEY DA ROCHA, Álvaro Filipe. O difícil processo de consolidação da cidadania plena no Brasil: notas sobre o patrimonialismo, o clientelismo, a corrupção e a pobreza política. In: Revista do Direito, Santa Cruz do Sul, p. 146-165, jan. 2008. ISSN 1982-9957. Disponível em:

https://online.unisc.br/seer/index.php/direito/article/view/588. Acesso em: 10 jan. 2019. doi:https://doi.org/10.17058/rdunisc.v0i29.588.

EL-HINNAWI, Essam. Environmental Refugees. Nairobi: United Nations Environment Programme (UNEP), 1985. Apud RAIOL, Ivanilson Paulo Corrêa. Ultrapassando fronteiras: a proteção jurídica dos refugiados ambientais. Porto Alegre: Núria Fabris, 2010.

ESMPU (Escola Superior do Ministério Público da União). Dicionário de Direitos

Humanos, 2006. Disponível em: <www.esmpu.gov.br> Acesso em 05 de março. 2019.

FAPESP. Cientistas fazem balanço dos resultados da Rio+20. Disponível em: http://agencia.fapesp.br/cientistas-fazem-balanco-dos-resultados-da-rio20/16082/. Acesso em 05 fev 2019.

FERNANDES, Cláudio Tadeu Cardoso. A segurança ambiental e os dilemas da reconstrução nos países em desenvolvimento arrasados por catástrofes naturais e conflitos: cooperação internacional ou capitalismo de desastre? Universitas - Rel. Int., Brasília, v. 4, n. 1, jan./jul. 2006, p. 89- 92. 
Glossário sobre Migração. Suiça, 2009 Disponível em:

http://publications.iom.int/system/files/pdf/iml22.pdf Acesso em 28 de março de 2019.

GIDDENS, Anthony. Capitalismo e moderna teoria social. 6. ed. Lisboa: Editorial Presença, 2005.

JACOBSON, Jodi L. Environmental Refugees: A Yardstick of Habitability. Worldwatch Paper 86. Washington, D.C.: Worldwatch Institute, November, 1988. Apud RAMOS, Érika Pires. Refugiados ambientais: em busca de reconhecimento pelo Direito Internacional. Tese (Doutorado) - Faculdade de Direito, Universidade de São Paulo, São Paulo, 2011.

LÖWY, Michael. Ecologia e Socialismo. São Paulo: Cortez, 2005.

MARSHALL, T. H. Cidadania, classe social e status. Trad. Meton Porto Gadelha. Rio de Janeiro: Zahar Editores, 1967.

MELLO, Celso Antônio Bandeira de. Elementos de Direito Administrativo. 3. ed., São Paulo: Malheiros, 1992, p. 299-300

MYERS, Norman. Environmental refugees: a growing phenomenon of the 21st century. Disponível em: http://www.nicholas.duke.edu/people/faculty/myers/myers2001.pdf. Acesso em: 20 mar. 2019.

NASCIMENTO, Humberto Miranda do. CAPITALISMO GLOBALIZADO E RECURSOS TERRITORIAIS: FRONTEIRAS DA ACUMULAÇÃO NO BRASIL CONTEMPORÂNEO, 2010 in Revista Brasileira de Estudos Urbanos e Regionais - v.13, n.2, 2011. - Associação Nacional de Pós-Graduação e Pesquisa em Planejamento Urbano e Regional; editor responsável Sarah Feldman : A Associação, 2011.

OLIVEIRA, Ariana Bazzano de. O percurso do conceito de paz: de Kant à atualidade. 1o Simpósio em Relações Internacionais do Programa de Pós-graduação em Relações

Internacionais San Tiago Dantas (UNESP, UNICAMP E PUC-SP). São Paulo, 12 a 14 de novembro de 2007. Disponível em:

http://www.santiagodantassp.locaweb.com.br/br/simp/artigos/bazzano.pdf. Acesso em: 17 março. 2019.

ONU, Assembleia Geral. A/RES/43/131. 75th plenary meeting. 8 dez. 1988. Disponível em: http://www.un.org/documents/ga/res/43/a43r131.htm. Acesso em: 20 março. 2019.

ONU, 53/243. ORGANIZAÇÃO DAS NAÇÕES UNIDAS. Declaração e Programa de Ação sobre uma Cultura de Paz Disponível em:

http://www.comitepaz.org.br/download/Declaração\%20e\%20Programa\%20de\%20Ação\%20s obre\%20uma\%20Cultura\%20de\%20Paz\%20-\%20ONU.pdf Acesso em: 20 março. 2019.

OST, François. A natureza à margem da lei: a ecologia à prova do direito. Lisboa: Piaget, 1997. 
PIOVESAN, Flávia. Temas de direitos humanos. $3^{\text {a }}$ ed. São Paulo: Saraiva, 2009.

PNUMA. Environmental Refugees, 1985. Disponível em: <www.liser.eu/pt>. Acesso em 03 mar. 2013.

RENNER, Michael. National security: the economic and environmental dimensions. Worldwatch Paper 89. Washington, D.C.: Worldwatch Institute, May 1989, p. 6. Disponível em:

https://books.google.com.br/books?id=t_vFPUNz8TEC\&pg=PA119\&lpg=PA119\&dq=REN NER,+Michael.+National+security:+the+economic+and+environmental+dimensions.+World watch+Paper+89.+Washington,+D.C.:+Worldwatch+Institute,+May+1989\&source=bl\&ots= C--7SEk23Z\&sig=ACfU3U1e2Fsi6AHVUeP4B KsVlaei9cwFMA\&hl=pt-

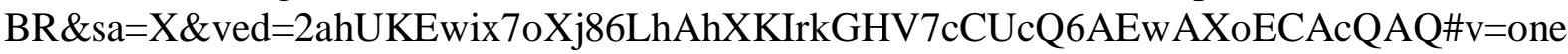
page\&q=RENNER\%2C\%20Michael. \%20National\%20security $\% 3 \mathrm{~A} \% 20$ the $\% 20$ economic $\% 2$ 0and $\% 20$ environmental\%20dimensions. $\% 20$ Worldwatch $\% 20$ Paper\%2089.\%20Washington $\%$ 2C\%20D.C. $\% 3$ A $\% 20$ Worldwatch $\% 20$ Institute $\% 2$ C\%20May\%201989\&f=false Acesso em: 24 de março de 2019.

SARLET, Ingo Wolfgang. A eficácia dos direitos fundamentais: uma teoria geral dos direitos fundamentais na perspectiva constitucional. $15^{\circ} \mathrm{ed}$. Porto Alegre: Livraria do Advogado, 2018.

SQUEFF, Tatiana Cardoso. A relevância do Pacto Global de Migrações no mundo contemporâneo In: Revista Consultor Jurídico, 27 de dezembro de 2018. Disponível em: https://www.conjur.com.br/2018-dez-27/tatiana-squeff-relevancia-pacto-global-migracoesmundo?imprimir=1. Acesso em $30 \mathrm{dez} 2018$.

TAMER, Alexandre dos Santos; POTEZZI, Valmor Cezar. A imigração haitiana e a criminalidade no município de Manaus. REVISTA DO DIREITO PÚBLICO, Londrina, v.8, n.3, p.55-76, set./dez.2013. Disponível em: http://www.uel.br/revistas/uel/index.php/direitopub/article/view/16584/13745 Acesso em 24 de março de 2019. 